\title{
Postharvest quality of 'Galaxy' apples submitted to the treatment with 1-MCP and different cooling times between harvest and cold storage
}

\author{
Crizane Hackbarth ${ }^{1}$ Cristiano André Steffens ${ }^{2}$ Cassandro Vidal Talamini do Amarante ${ }^{2}$ \\ Mayara Cristiana Stanger ${ }^{2}$ Auri Brackmann ${ }^{3}$
}

\author{
${ }^{1}$ Universidade Federal do Paraná (UFPR), Rua dos Funcionários, 1540, 80035-050, Curitiba, PR, Brasil. E-mail: crizanehackbarth@hotmail.com. \\ Corresponding author. \\ ${ }^{2}$ Centro de Ciências Agroveterinárias (CAV), Universidade do Estado de Santa Catarina (UDESC), Lages, SC, Brasil. \\ ${ }^{3}$ Centro de Ciências Rurais (CCR), Universidade Federal de Santa Maria (UFSM), Santa Maria, RS, Brasil.
}

\begin{abstract}
In this research it was evaluated if the use of 1-methylcyclopropene (1-MCP), associated to different cooling times between the harvest and storage, replaces the pre-cooling in 'Galaxy' apples. Treatments were arranged in a factorial scheme, combining the following factors: application of 1-MCP (with or without) and different times between harvest and cooling (24 hours, 96 hours, 144 hours and 192 hours in 2013; and 24 hours, 48 hours, 144 hours and 240 hours in 2014). After four months of cold storage $\left(1.0 \pm 0.2^{\circ} \mathrm{C} / 92 \pm 5 \%\right.$ RH - Relative Humidity) were evaluated: flesh firmness, texture, titratable acidity (TA), soluble solids (SS) and skin color. Apples treated with 1-MCP showed greater flesh firmness, texture and SS, in both years, and more TA and lower incidence of mealy flesh compared to apples not treated with 1-MCP in 2013. The 1-MCP was effective in maintaining the fruit quality, even with the cooling delay of up to 240 hours. Cooling delay of 192 hours and 240 hours in 'Galaxy' apples not treated with 1-MCP should be avoided because it reduces the quality of fruits.
\end{abstract}

Key words: cooling delay, fast cooling, Malus domestica Borkh.

Qualidade pós-colheita de maçãs 'Galaxy' submetidas ao tratamento com 1-MCP e diferentes tempos de resfriamento entre a colheita e 0 armazenamento refrigerado

RESUMO: Neste trabalho avaliamos se o uso de 1-metilciclopropeno (1-MCP), associado com diferentes tempos de resfriamento entre a colheita e o armazenamento, substitui o pré-resfriamento em maçãs 'Galaxy'. Os tratamentos foram arranjados em esquema fatorial, combinando os fatores aplicação de 1-MCP (com ou sem) e diferentes tempos entre a colheita e o resfriamento (24h, 96h, 144h e 192h, em 2013; e 24h, 48h, $144 \mathrm{~h}$ e 240h, em 2014). Após quatro meses de armazenamento refrigerado (1,0 $\pm 0,2{ }^{\circ} \mathrm{C} / 92 \pm 5 \%$ de UR), foram avaliados: firmeza de polpa, textura, acidez titulável (AT), sólidos solúveis (SS) e cor da epiderme. As maçãs tratadas com 1-MCP apresentaram maior firmeza de polpa, textura e SS, em ambos os anos, e maior AT e menor incidência de polpa farinácea em comparação a maçãs não tratadas com 1-MCP, em 2013. O 1-MCP foi eficaz em manter a qualidade dos frutos, mesmo com o retardo do resfriamento em até $240 h$. $O$ retardo do resfriamento de $192 \mathrm{~h}$ e $240 \mathrm{~h}$ em maçãs 'Galaxy' não tratadas com 1-MCP deve ser evitado, pois diminui a qualidade dos frutos.

Palavras-chave: retardo do resfriamento, resfriamento rápido, Malus domestica Borkh.

\section{INTRODUCTION}

The biggest part of apples production is intended for storage, which allows the commercialization for long periods after harvest (MAZZURANA et al., 2016). When compared to other fruits, apples can be stored for a longer period of time (STEFFENS et al., 2008). However, 'Gala' apples and their mutant clones, due to its high respiration rates and ethylene biosynthesis, show a fast loss of flesh firmness, skin yellowing and reduction of titratable acidity during cold storage (CS)
(BRACKMANN et al., 2005). Use of refrigeration has been associated to other practices, such as precooling, gas control in controlled atmosphere (CA) and fruits treatment with 1-methylcyclopropene (1$\mathrm{MCP}$ ), in order to increase fruits conservation quality potential after harvest (McCORMICK et al., 2010; MAZZURANA et al., 2016).

In order to prolong the maintenance of quality, it is recommend the apples fast cooling or pre-cooling (BRACKMANN et al., 2005). Slow cooling has some advantages and disadvantages. As a benefit it can be mentioned the reduction of 
the fruits susceptibility to injury caused by cold. However, the delay in the fruits cooling can cause quality loss. Although, some studies show that fast cooling allows a better maintenance of apples quality, such as increased flesh firmness and retention of skin green color (BRACKMANN et al., 2005), there are still some doubts among producers and stores about the effectiveness of this procedure. In addition, during the harvest the packing house receives a large volume of fruits daily, which makes impossible the fast cooling of the fruits (LUNARDI et al., 2004). This problem is aggravated in smaller companies facing difficulties involved in harvesting, transporting and cooling capacity. In these situations, it is common that the cooling of the fruit to take eight to ten days before the fruit reaches storage temperature (LUNARDI et al., 2004).

Use of 1-MCP in apple storage was intensified because the 1-MCP effectively inhibits the action of ethylene and controls the maturation and senescence of fruits (McCORMICK et al., 2010; AMBAW et al., 2011; MAZZURANA et al., 2016). In 'Pink Lady' apples, the application of 1-MCP reduced the ethylene synthesis and kept stable the acidity and flesh firmness after cold storage for six months (COCCI et al., 2014). In 'McIntosh' and 'Empires' apples, the treatment with 1-MCP showed higher flesh firmness, even with a delay of up to 14 days in the installation of controlled atmosphere (WATKINS \& NOCK, 2012).

The objective of this study was to evaluate the application effect of 1-MCP, associated to different cooling times between harvest and cold storage of 'Galaxy' apples as a method to dispense the fruits pre-cooling, without compromising the quality and the storage potential.

\section{MATERIALS AND METHODS}

The 'Galaxy' apples were harvested in a commercial orchard located in Vacaria, Rio Grande do Sul (Brazil) (28 30'44”S latitude, 50 56’ 02”W longitude, 970 meters high) in 2013 and 2014. After the harvest and transportation to the Laboratory of Postharvest Physiology and Technology of CAV/ UDESC (Universidade do Estado de Santa Catarina - Brazil) in Lages, SC, it was proceeded the selection of fruits, eliminating the damaged fruits. In order to homogenize the initial temperature of the fruits, the samples were stored for twelve hours in a chamber B.O.D. brand Eletrolab in a temperature of $28 \pm 1^{\circ} \mathrm{C}$.

In 2013 the experiment was conducted in bifactorial scheme $2 \times 5$ and the treatments were originated from the combination between the factors: 1-MCP (with and without) and different cooling times between harvest and cold storage (CS) (24 hours, 96 hours, 144 hours, 192 hours and 240 hours). In 2014 season, the bifactorial scheme was $2 \times 4$, being the treatments the combination of two levels of the factors: 1-MCP (with and without) and four levels of the cooling period factor between harvest and cold storage (CS) (24 hours, 48 hours, 144 hours and 240 hours). Cooling periods were the time until the fruits flesh reached $1 \pm 0.2^{\circ} \mathrm{C}$.

The application of 1-MCP was performed after the homogenization of fruits temperature at $28^{\circ} \mathrm{C}$. As source of $1-\mathrm{MCP}$ was used the product called Smart Fresh ${ }^{\circledR}(0.14 \%$ 1-MCP in a powder formulation). The dose of $1-\mathrm{MCP}$ was $1 \mu \mathrm{L} \mathrm{L}^{-1}$. The product was solubilized in water at environmental temperature and the 1-MCP gas was released inside an aluminum chamber of $0.42 \mathrm{~m}^{3}$ with hermetic closure. Fruits were exposed to treatment for 24 hours.

The fruits, treated and not treated with 1-MCP, were submitted to different cooling times after the 24 hours time required for the application of 1-MCP. The fruits cooling was held in chamber B.O.D. Eletrolab brand, with gradual reduction of temperature, every day, until the flesh fruits reached the temperature of $1 \pm 0.2^{\circ} \mathrm{C}$ at the end of each period (24 hours, 96 hours, 144 hours, 192 hours and 240 hours in 2013 and 24 hours, 48 hours, 144 hours and 240 hours in 2014). After this, the 'Galaxy' apples were stored for four months at $1 \pm 0.2^{\circ} \mathrm{C} / \mathrm{RH} 92 \pm 5 \%$.

In 2013, it was accomplished two assessments of fruits quality, in the chamber outlet and after seven days of fruits exposure at environmental conditions $\left(18 \pm 5^{\circ} \mathrm{C}\right.$ and $65 \pm 5 \%$ of RH). In 2014 , the fruits quality was evaluated after seven days of fruit exposure at environmental conditions $\left(18 \pm 5^{\circ} \mathrm{C}\right.$ and $65 \pm 5 \%$ of $\mathrm{RH})$. The variables analyzed were flesh firmness, force to the flesh penetration and the skin rupture, titratable acidity, soluble solids, skin color (Hue angle), and incidence of mealy pulp.

Flesh firmness $(\mathrm{N})$ was determined in the equatorial region of the fruits, measured at two opposite sides after the removal of a small portion of the skin, using an electronic penetrometer (GÜSS Manufacturing Ltd., South Africa) fitted with an $11.1 \mathrm{~mm}$ diameter head. Texture attributes $(\mathrm{N})$ were analyzed with an electronic texturometer TAXTPlus $^{\circledR}$ (Stable Micro Systems Ltd., UK) in terms of forces to skin rupture (FSR) and to flesh penetration (FFP), using a probe trial model PS2 with $2 \mathrm{~mm}$ diameter, which was introduced into the pulp at a depth of $10 \mathrm{~mm}$. Incidence of mealy pulp (\%) was 
determined by the quantifying of fruits which showed dry pulp and little juiciness in relation to the total number of fruits.

The titratable acidity values (TA;\% malic acid) were obtained from a sample of $10 \mathrm{~mL}$ of fruit juice, extracted from transverse slices removed from the equatorial region of the apples and ground in an electric centrifuge. This sample was diluted in $90 \mathrm{~mL}$ of distilled water and titrated with sodium hydroxide solution $0.1 \mathrm{~N}$ to $\mathrm{pH} 8.1$ using an automatic titrator (Radiometer, Copenhagen, Denmark). Soluble solids levels (SS; ${ }^{\circ}$ Brix) were determined by refractometry, with a digital refractometer PR201 $\alpha$ model (Atago, Japan). Juice was extracted as described for the TA, being accomplished the correction of the temperature effect $\left(20^{\circ} \mathrm{C}\right)$. The determination of the skin color (Hue angle) was made with a Minolta colorimeter CR 400 model. Readings were taken in the equatorial region of the fruits. The Hue angle defines the basic color, being $0^{\circ}=$ red, $90^{\circ}=$ yellow and $180^{\circ}=$ green .

Apples at the time of experiments installation, showed, respectively, in 2013 and 2014, TA $0.330 \%$ and $0.311 \%$ of malic acid; SS level of $11.9^{\circ}$ Brix and $12.2^{\circ}$ Brix; and skin color (Hue angle) of 71.9 and 81.2. In both experiments, the experimental design was the completely randomized one with four replications and the experimental unit of 20 fruits. Data were submitted to the analysis of variance (ANOVA), and mealy pulp incidence values were previously transformed by the formula arcsine $[(\mathrm{x}+0,5) / 100]^{1 / 2}$ and the treatment averages were compared by the Tukey test $(\mathrm{P}<0.05)$.

\section{RESULTS AND DISCUSSION}

In 2013 there was a significant interaction between the factors application of 1-MCP and cooling period of the fruits to force to flesh penetrate, at the exit of the chamber, and incidence of mealy flesh, at the exit of the chamber and after seven days on the shelves. In 2014 there was an interaction between treatment with 1-MCP and cooling time for flesh firmness, strength to skin rupture and flesh penetration, incidence of mealy pulp and TA.

The flesh firmness was higher in fruits treated with 1-MCP than in untreated fruits, in 2013, regardless the cooling period of the fruits (Table 1). In 2014, 1-MCP had no significant effect on flesh firmness in cold fruits in 24 hours, but it kept the higher flesh firmness in other cooling times, compared to fruits not treated with 1-MCP (Table 2). Related to the texture attributes, it was apparent the effect of 1-MCP in the maintenance of forces for skin rupture (FSR), and forces for flesh penetration (FFP). The effect of 1-MCP on the maintenance of 'Gala' apples flesh firmness has been reported by several authors (WATKINS \& NOCK, 2012; COCCI et al., 2014; MAZZURANA et al., 2016), corroborating with results of this research. The effect of 1-MCP in maintaining flesh firmness and texture attributes is due to the inhibition of ethylene action (WEI et al., 2010), which in turn decreases the activity of pectolytic enzymes (LUNARDI et al., 2004).

In 2013, there was no effect of cooling delay on flesh firmness (Table 1). However, in 2014, the fruits not treated with 1-MCP had a greater reduction of flesh firmness in fruits submitted to slow cooling (240 hours) (Table 2). For the texture attributes in 2013, at the exit of the chamber, the cooling delay decreased the FSR, independent of the application of 1-MCP, and reduced the FFP in fruits not treated with 1-MCP (Table 1). The FSR values were higher in the cooling in 24 hours, when compared to the cooling in 144 hours and 240 hours. In fruits not treated with 1-MCP, the cooling in 24 hours provided higher FFP compared to fruit cooled in 192 hours and 240 hours. However, when it was applied 1-MCP, the cooling delay had no effect on the FFP in 'Galaxy' apples. After seven days of fruits exposure at environmental conditions, the fruits cooled in 24 hours showed a higher FSR compared to fruits with cooling in 240 hours (Table 1). Possibly, these results are related to the most intense metabolism in the beginning of storage in fruits submitted to slow cooling, especially those not treated with 1-MCP.

In 2014 it was not observed effect of cooling delay on FSR and FFP in fruits not treated with 1-MCP. However, in fruits treated with 1-MCP, surprisingly the cooling in 24 hours showed lower FSR and FFP in relation to the cooling times of 48 hours, 144 hours and 240 hours (Table 2). There was no synergistic effect between the cooling in 24 hours and the application of 1-MCP on the maintenance of flesh firmness and texture attributes. Fruits treated with 1-MCP and submitted to cooling for 240 hours showed higher values of flesh firmness and texture attributes than the fruits not treated with 1-MCP and refrigerated for 24 hours. Results observed both in flesh firmness and in texture attributes of 'Galaxy' apples, showed that 1-MCP is more effective in maintaining the flesh firmness and fruit texture than the fast cooling.

In fruits treated with 1-MCP, in 2013, the incidence of mealy pulp was not detected at the exit of the chamber. After seven days in environmental conditions there was a low incidence $(<3 \%)$ in fruits with 24 hours and 96 hours of cooling, but 
Table 1 - Flesh firmness, force to skin rupture (FSR) and force to flesh penetration (FFP) and incidence of mealy pulp in 'Galaxy' apples submitted to the treatment with 1-MCP (c/1-MCP) or without 1-MCP (s/1-MCP) and different cooling times between harvest and cold storage (2013).

\begin{tabular}{|c|c|c|c|c|c|c|c|c|c|c|c|c|}
\hline \multirow{2}{*}{ 1-MCP } & \multicolumn{5}{|c|}{------------------Cooling times (h)---------------- } & \multirow{2}{*}{ Average } & \multicolumn{5}{|c|}{------------------Cooling times (h)----------------- } & \multirow{2}{*}{ Average } \\
\hline & 24 & 96 & 144 & 192 & 240 & & 24 & 96 & 144 & 192 & 240 & \\
\hline & \multicolumn{6}{|c|}{-------------------------Chamber outlet------------------------ } & \multicolumn{6}{|c|}{ 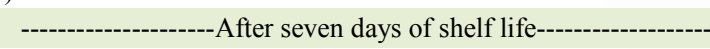 } \\
\hline $\mathrm{s} / 1-\mathrm{MCP}$ & 52 & 50.5 & 49.6 & 46.1 & 46.7 & $49 \mathrm{~B}$ & 45.9 & 50.3 & 48.8 & 48.6 & 47.8 & $48.3 \mathrm{~B}$ \\
\hline $\mathrm{c} / 1-\mathrm{MCP}$ & 72.9 & 67.9 & 70.3 & 70.8 & 68.9 & $70.6 \mathrm{~A}$ & 70.2 & 67.4 & 71.7 & 70.9 & 69.1 & $69.8 \mathrm{~A}$ \\
\hline Average & $62.4^{\mathrm{ns}}$ & 59.2 & 59.9 & 59.5 & 57.8 & & $58.1^{\mathrm{ns}}$ & 58.5 & 60.3 & 59.8 & & \\
\hline \multirow[t]{2}{*}{$\mathrm{CV}(\%)$} & \multicolumn{5}{|c|}{5.60} & \multicolumn{6}{|c|}{4.30} & \\
\hline & \multicolumn{6}{|c|}{------------------------Chamber outlet------------------------ } & \multicolumn{6}{|c|}{ 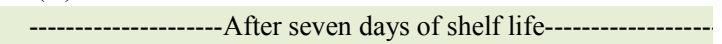 } \\
\hline $\mathrm{s} / 1-\mathrm{MCP}$ & 9.3 & 9.6 & 8.8 & 8.8 & 8,3 & $8,9 \mathrm{~B}$ & 12.6 & 12 & 12.6 & 12.2 & 11.7 & $12.2 \mathrm{~A}$ \\
\hline $\mathrm{c} / 1-\mathrm{MCP}$ & 13.4 & 12.4 & 12 & 12.5 & 12 & $12,5 \mathrm{~A}$ & 8.6 & 8.5 & 8.3 & 8.5 & 8.2 & $8.4 \mathrm{~B}$ \\
\hline Average & $11.4 \mathrm{a}$ & $11 \mathrm{ab}$ & $10.4 \mathrm{~b}$ & $10.6 \mathrm{ab}$ & $10.2 \mathrm{~b}$ & & $10.6 \mathrm{a}$ & $10.2 \mathrm{ab}$ & $10.4 \mathrm{ab}$ & $10.3 \mathrm{ab}$ & $9.9 \mathrm{~b}$ & \\
\hline \multirow[t]{2}{*}{$\mathrm{CV}(\%)$} & \multicolumn{6}{|c|}{5.50} & \multicolumn{5}{|c|}{4.50} & \\
\hline & \multicolumn{6}{|c|}{ 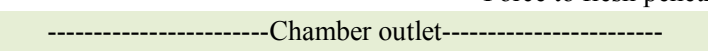 } & \multicolumn{6}{|c|}{------After seven days of shelf life------------- } \\
\hline s/1-MCP & $2.2 \mathrm{Ba}$ & $1.9 \mathrm{Bab}$ & 1.9 Bab & $1.8 \mathrm{Bb}$ & $1.8 \mathrm{Bb}$ & 2 & 1,9 & 1,8 & 1,8 & 1,8 & 1,9 & $1,8 \mathrm{~B}$ \\
\hline $\mathrm{c} / 1-\mathrm{MCP}$ & $2.8 \mathrm{Aa}$ & $2.9 \mathrm{Aa}$ & $2.8 \mathrm{Aa}$ & $2.9 \mathrm{Aa}$ & $2.8 \mathrm{Aa}$ & 2.8 & 2.6 & 2.4 & 2.7 & 2.6 & 2.5 & $2.6 \mathrm{~A}$ \\
\hline Average & 2.5 & 2.4 & 2.4 & 2.4 & 2.3 & & $2.3^{\mathrm{ns}}$ & 2.1 & 2.2 & 2.2 & 2.2 & \\
\hline CV $(\%)$ & \multicolumn{5}{|c|}{5.50} & & \multicolumn{5}{|c|}{5.30} & \\
\hline & \multicolumn{6}{|c|}{------------------------Chamber outlet------------------------ } & \multicolumn{6}{|c|}{-----After seven days of shelf life------------- } \\
\hline $\mathrm{s} / 1-\mathrm{MCP}$ & $30.2 \mathrm{Ab}$ & $27.5 \mathrm{Ab}$ & $43.3 \mathrm{Aab}$ & $65 \mathrm{Aa}$ & $40.2 \mathrm{Aab}$ & 41.2 & $60.2 \mathrm{Aa}$ & $28.2 \mathrm{Ab}$ & 47.5 Aab & $50.5 \mathrm{Aab}$ & 51.8 Aab & 47.6 \\
\hline $\mathrm{c} / 1-\mathrm{MCP}$ & $0 \mathrm{Ba}$ & $0 \mathrm{Ba}$ & $0 \mathrm{Ba}$ & $0 \mathrm{Ba}$ & $0 \mathrm{Ba}$ & 0 & $2.5 \mathrm{Ba}$ & $1.9 \mathrm{Ba}$ & $0 \mathrm{Ba}$ & $0 \mathrm{Ba}$ & $0 \mathrm{Ba}$ & 0.7 \\
\hline Average & 15.1 & 13.8 & 21.7 & 32.5 & 20.1 & & 31.3 & 15.1 & 23.75 & 25.3 & 25.9 & \\
\hline $\mathrm{CV}(\%)$ & \multicolumn{6}{|c|}{26.40} & \multicolumn{5}{|c|}{21.80} & \\
\hline
\end{tabular}

Means followed by at least one common letter, lowercase in the line and uppercase in the column, did not differ significantly by Tukey test $(\mathrm{P}<0.05) .{ }^{\text {ns. }}$. No significant difference $(\mathrm{P}<0.05)$.

without significant differences between cooling times (Table 1). In 2014, fruits treated with 1-MCP showed lower incidence of mealy pulp when compared to fruits not treated with 1-MCP. The cooling delay did not influence the incidence of this disorder in the evaluated fruits. In both evaluations, the incidence of the disorder was high in fruits with no application of 1-MCP, regardless the cooling time of the fruits. This confirmed the results already published by other authors, showing reduction in the occurrence of physiological disorders associated to the senescence of fruits by the application of 1-MCP (WATKINS et al., 2006; MAZZURANA et al., 2016). The efficiency of MCP-1 in reducing this physiological disorder occurred through the inhibition of the ethylene action, since ethylene increases the incidence of mealy pulp since it accelerates the fruits senescence (STEFFENS et al., 2008). At the exit of the chamber, apples which were not treated with 1-MCP and cooled in 192 hours showed a higher incidence of mealy pulp, differing from apples cooled in 24 hours and 96 hours. After seven days of fruit exposure in environmental conditions, apples cooled in 24 hours showed higher incidence of mealy pulp, differing only from fruits cooled in 96 hours, which had lower incidence. These results suggested that the cooling delay of 'Galaxy' apples can cause a higher incidence of mealy pulp in fruits not treated with 1-MCP. However, the fast cooling may raise stress by low temperature in fruits, inducing the manifestation of the disorder during the commercialization time.

In 2013, TA was higher in apples treated with 1-MCP than in untreated ones at the exit chamber and after more seven days of exposure in environmental 
Table 2 - Flesh firmness, force to skin rupture (FSR) and force to flesh penetration (FFP), incidence of mealy pulp, titratable acidity, soluble solids and skin color in 'Galaxy' apples submitted to the treatment with 1-MCP (c/1-MCP) or without 1-MCP (s/1-MCP) and different cooling times between harvest and cold storage (2014).

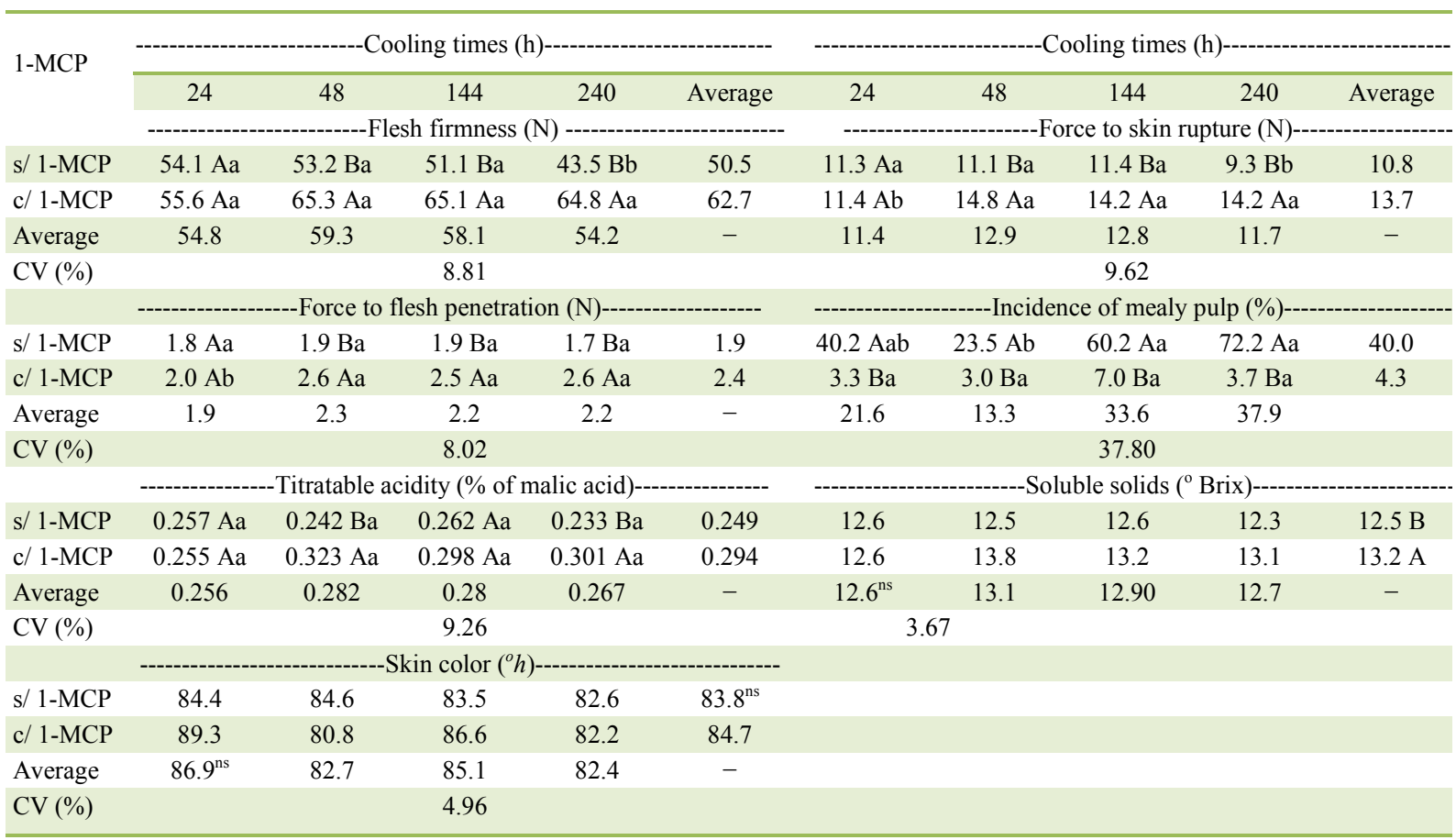

Means followed by at least one common letter, lowercase in the line and uppercase in the column, did not differ significantly by Tukey test $(\mathrm{P}<0.05) .{ }^{\mathrm{ns}}$ : No significant difference $(\mathrm{P}<0.05)$.

conditions (Table 3). Several authors reported higher TA in apples treated with 1-MCP (FAN et al., 1999; WATKINS et al., 2000; BRACKMANN et al., 2004; CORRENT et al., 2005), which may be related to lower consumption of acids in the tricarboxylic acids cycle, since the 1-MCP reduces the respiration rate of fruits (WATKINS et al., 2000; BRACKMANN et al., 2005). The fruits with retardation of storage 240 hours showed TA lower than the fruits with cooling delay of 144 hours, at the exit of the chamber. Although, the cooling treatment of 240 hours did not show significant difference when compared to 24 hours and 96 hours of cooling, it is noted that there was a decrease in TA with the increase in cooling time. In 2014 there was no difference in the TA between cooling periods, regardless the application of 1-MCP. The 1-MCP provided greater TA when apples were cooled in 48 hours and 240 hours (Table 2).

The SS level, in both years of experimental evaluation, was larger in 'Galaxy' apples treated with 1-MCP (Tables 2 and 3). COCCI et al. (2014) reported that the SS content may be greater in apples treated with 1-MCP. The greater SS level in 'Galaxy' apples treated with 1-MCP is possibly related to lower respiration rate of these fruits, because sugars as well as organic acids serve as substrates for respiration.

In 2013 there was no difference between treatments for skin color, at the chamber exit. After seven days of fruits exposure in environmental conditions, the application of 1-MCP provided better retention of skin green color(Table 3). BRACKMANN et al. (2005) reported higher retention of green color in 'Gala' apples treated with 1-MCP. The cooling delay had no effect on skin color. In 2014 it was not observed differences among treatments for skin color (Table 2).

\section{CONCLUSION}

The 1-MCP was efficient in maintaining the quality of 'Galaxy' apples after four months of cold storage, allowing a cooling delay in until 10 days (240 hours). When it is not done the treatment of 'Galaxy' apples with 1-MCP, eight days (192 hours) 
Table 3 - Titratable acidity, soluble solids and skin color of 'Galaxy' apples submitted to the treatment with 1-MCP (c/1-MCP) or without 1MCP (s/1-MCP) and different cooling times between harvest and cold storage (2013).

\begin{tabular}{|c|c|c|c|c|c|c|c|c|c|c|c|c|}
\hline \multirow{2}{*}{ 1-MCP } & \multicolumn{6}{|c|}{ 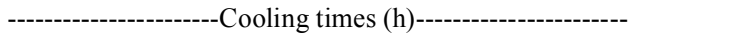 } & \multicolumn{6}{|c|}{ 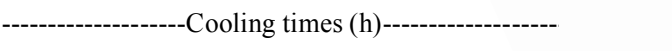 } \\
\hline & 24 & 96 & 144 & 192 & 240 & Average & 24 & 96 & 144 & 192 & 240 & Average \\
\hline \multirow{2}{*}{\multicolumn{13}{|c|}{ - }} \\
\hline & & & & & & & & & & & & \\
\hline s/ 1-MCP & 0.26 & 0.25 & 0.26 & 0.23 & 0.22 & $0.24 \mathrm{~B}$ & 0.22 & 0.22 & 0.22 & 0.21 & 0.22 & $0.22 \mathrm{~B}$ \\
\hline c/ 1-MCP & 0.30 & 0.31 & 0.31 & 0.31 & 0.30 & $0.31 \mathrm{~A}$ & 0.26 & 0.26 & 0.29 & 0.28 & 0.26 & $0.28 \mathrm{~A}$ \\
\hline Average & $0.28 \mathrm{ab}$ & $0.28 \mathrm{ab}$ & $0.29 \mathrm{a}$ & $0.27 \mathrm{ab}$ & $0.26 \mathrm{~b}$ & - & $0.24^{\mathrm{ns}}$ & 0.25 & 0.26 & 0.25 & 0.24 & - \\
\hline CV (\%) & & & 6.80 & & & - & & & 10.30 & & & - \\
\hline \multicolumn{13}{|c|}{ - } \\
\hline & 13 & 126 & 120 & 123 & 123 & $127 \mathrm{R}$ & 123 & 125 & 128 & & 126 & $125 \mathrm{~B}$ \\
\hline S/ $1-1$ & 15 & 12.0 & 12.9 & 12.3 & 12.3 & & 12.3 & 12.5 & 12.0 & & 12.0 & $12.5 \mathrm{~B}$ \\
\hline c/ 1-IVIC & 13.2 & 15.1 & 15.4 & 15.4 & 15.1 & $15.2 \mathrm{~A}$ & 13.1 & 12.8 & 13 & 2 & 13.1 & $13 \mathrm{~A}$ \\
\hline Average & $13.1^{\mathrm{ns}}$ & 12.9 & 13.2 & 12.9 & 12.7 & - & & 12.6 & 12.9 & 12.7 & 12.8 & - \\
\hline CV (\%) & & & 4.30 & & & - & & & 5.20 & & & - \\
\hline \multirow{2}{*}{\multicolumn{13}{|c|}{ 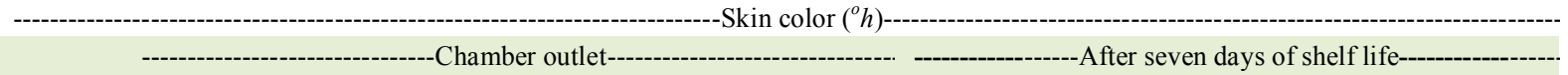 }} \\
\hline & & & & & & & & & & & & \\
\hline s/ 1-MCP & 46.3 & 49.2 & 54.9 & 57.5 & 59.5 & 52.4 & 68 & 66.2 & 64.8 & 70.5 & 64.5 & $66.1 \mathrm{~B}$ \\
\hline c/ 1-MCP & 59.6 & 56.3 & 56.9 & 56.9 & 55.2 & $56.4^{\mathrm{ns}}$ & 67.9 & 74.1 & 71.9 & 67.8 & 71.2 & $70.6 \mathrm{~A}$ \\
\hline Average & $52.9^{\mathrm{ns}}$ & 52.8 & 55.9 & 57.2 & 57.3 & - & $67.9^{\mathrm{ns}}$ & 70.2 & 68.4 & 69.2 & 67.8 & - \\
\hline CV (\%) & & & 10.90 & & & - & & & 6.70 & & & - \\
\hline
\end{tabular}

Means followed by at least one common letter, lowercase in the line and uppercase in the column, did not differ significantly by Tukey test $(\mathrm{P}<0.05) .{ }^{\text {ns }}$ : No significant difference $(\mathrm{P}<0.05)$.

of delay in the cooling of the fruits affects the quality of 'Galaxy' apples after cold storage, especially by reduction of flesh firmness, texture attributes and titratable acidity of the fruit.

\section{ACKNOWLEDGEMENTS}

The authors acknowledge Coordenação de Aperfeiçoamento de Pessoal de Nível Superior (CAPES) and Conselho Nacional de Desenvolvimento Científico e Tecnológico (CNPq) for scholarships and research fellowship.

\section{REFERENCES}

AMBAW, A. et al. Modeling the diffusion-adsorption kinetics of 1-methylcyclopropene (1-MCP) in apple fruit and non-target materials in storage rooms. Journal of Food Engineering, London, v.102, p.257-265, 2011. Available from: <https:// goo.gl/WmXcUC $>$. Accessed: Aug. 01, 2014. doi: 10.1016/j. jfoodeng.2010.08.028.

BRACKMANN, A. et al. Quality of apples cv. 'Gala' treated with 1-methylcyclopropene. Ciência Rural, Santa Maria, v.34, n.5, p.1415-1420, 2004. Available from: <https://goo. gl/A3Duph>. Accessed: Dec. 12, 2014. doi: 10.1590/S010384782004000500014

BRACKMANN, A. et al. Fast cooling and rapid controlled atmosphere as substitute of 1-MCP on 'Gala' apple fruits storage.
Revista Brasileira de Fruticultura, Jaboticabal, v.27, n.3, p.379382, 2005. Available from: <https://goo.gl/hlwzEb>. Accessed: July 07, 2014. doi: 10.1590/S0100-29452005000300010.

COCCI, E. et al. Response of Pink Lady ${ }^{\circledR}$ apples to postharvest application of 1-methylcyclopropene as a function of applied dose, maturity at harvest, storage time and controlled atmosphere storage. Journal of the Science Food and Agriculture, London, v.94, p.2691-2698, 2014. Available from: <https://goo.gl/sEKHDw>. Accessed: Dec. 19, 2014. doi: 10.1002/jsfa.6610.

CORRENT, A.R. et al. 1-Methylcyclopropene in the control of the ripening and in maintenance of quality of 'Royal Gala' apples. Revista Brasileira de Fruticultura, Jaboticabal, v.27, n.2, p.207210, 2005. Available from: <https://goo.gl/GEc4WK>. Accessed: Aug. 01, 2012. doi: 10.1590/S0100-29452005000200006.

FAN, X. et al. 1-Methylcyclopropene inhibits apple ripening. Journal of the American Society for Horticultural Science, Alexandria, v.6, n.124, p.690-695, 1999. Available from: <https:// goo.gl/N7mtqZ>. Accessed: May 31, 2017.

LUNARDI, R. et al. Juiciness and pectins solubilization of 'Gala' apples submited to different cooling times and 1-methylcyclopropene application. Ciência e Agrotecnologia, Lavras, v.28, n.4, p.871-877, 2004. Available from: <https://goo. gl/rABU9Q $>$. Accessed: July 21, 2014. doi: 10.1590/S141370542004000400020 .

MAZZURANA, E.R. et al. Potential benefits of temperature increase during storage under controlled atmosphere of 'Gala' apples treated 
with 1-MCP. Revista Brasileira de Fruticultura, Jaboticabal, v.38, n.1, p.43-52, 2016. Available from: <https://goo.gl/5rbwZx >. Accessed: Sept. 29, 2016. doi: 10.1590/0100-2945-237/14.

McCORMICK, R. et al. A case study: potential energy savings using 1-MCP with 'Gala' apples in commercial CA storage. Acta Horticulturae, Leuven, n.877, p.323-326, 2010. Available from: $<$ https://goo.gl/mBte3Z>. Accessed: May 31, 2017. doi: 10.17660/ ActaHortic.2010.877.39.

STEFFENS, C.A. et al. Respiration, ethylene production and quality of 'Gala' apples in function to impact injury and treatment with 1-methylcyclopropene. Ciência Rural, Santa Maria, v.38, n.7, p.1864-1870, 2008. Available from: <https://goo.gl/I3epFC >. Accessed: July 21, 2014. doi: 10.1590/S0103-84782008000700010.

WATKINS, C.B. The use of 1-methylcyclopropene (1-MCP) on fruits and vegetables. Biotechnology Advances, Kidlington, v.24, p.389-409, 2006. Available from: <https://goo.gl/WbsGwi> Accessed: May 31, 2017. doi: 10.1016/j.biotechadv.2006.01.005.
WATKINS, C.B.; NOCK, J.F. Rapid 1-methylcyclopropene (1-MCP) treatment and delayed controlled atmosphere storage of apples. Postharvest Biology and Technology, Amsterdam, v.69, p.24-31, 2012. Available from: <https:// goo.gl/37d8zH>. Accessed: May 31, 2017. doi: 10.1016/j. postharvbio.2012.02.010.

WATKINS, C.B. et al. Responses of early, mid and late season apple cultivars to postharvest application of 1-methylcyclopropene (1-MCP) under air and controlled atmosphere storage conditions. Postharvest Biology and Technology, Amsterdam, v.19, n.1, p.17-32, 2000. Available from: <https://goo.gl/JKpTkl>. Accessed: May 31, 2017. doi: 10.1016/S0925-5214(00)00070-3.

WEI, J. et al. Changes and postharvest regulation of activity and gene expression of enzymes related to cell wall degradation in ripening apple fruit. Postharvest Biology and Technology, Amsterdam, v.56, p.147-154, 2010. Available from: <https:// goo.gl/66tx44>. Accessed: May 31, 2017. doi: 10.1016/j. postharvbio.2009.12.003. 